\title{
FAULHABER, Priscila \& LEITE LOPES, José Sérgio (orgs.). 2012. Autoria e história cultural da ciência / Roger Chartier
}

\section{Christina de Rezende Rubim}

\section{(2) OpenEdition Journals}

Edição electrónica

URL: http://journals.openedition.org/aa/456

DOI: $10.4000 /$ aa. 456

ISSN: 2357-738X

Editora

Programa de Pós-Graduação em Antropologia Social (UnB)

\section{Edição impressa}

Data de publição: 1 junho 2013

Paginação: 281-284

ISSN: 0102-4302

\section{Refêrencia eletrónica}

Christina de Rezende Rubim, «FAULHABER, Priscila \& LEITE LOPES, José Sérgio (orgs.). 2012. Autoria e história cultural da ciência / Roger Chartier», Anuário Antropológico [Online], v.38 n.1 | 2013, posto online no dia 01 outubro 2013, consultado o 28 abril 2021. URL: http://journals.openedition.org/aa/ 456 ; DOI: https://doi.org/10.4000/aa.456

\section{(c) (i) (9)}

Anuário Antropológico is licensed under a Creative Commons Atribuição-Uso Não-Comercial-Proibição de realização de Obras Derivadas 4.0 International. 


\section{FALHAUBER, Priscila \& LEITE LOPES, José Sérgio (orgs.). 2012. Autoria e história cultural da ciência / Roger Chartier. Rio de Janeiro: Beco do Azougue. 124 pp.}

Christina de Rezende Rubim

UNESP, FFC

O livro Autoria e história cultural da ciência, de Roger Chartier, organizado por Priscila Falhauber e José Sérgio Leite Lopes, é fruto da visita ao Brasil do historiador francês no inverno de 2007, quando proferiu conferência no Museu de Astronomia e Ciências Afins (MAST) do Rio de Janeiro e concedeu entrevista aos organizadores, tendo participado de outras atividades acadêmicas.

A publicação está organizada em torno de cinco textos: a) a conferência de Roger Chartier, "História cultural do autor e da autoria”; b) o debate que se seguiu à conferência; c) o posfácio do autor; d) um bloco de comentários feitos pelos organizadores da coletânea; e) uma apresentação da historiadora Heloisa Maria Bertol Domingues.

O texto de Chartier - conhecido no Brasil por várias de suas obras apropriadas por diferentes campos do conhecimento, como história, educação e ciências sociais - é o que confere amálgama ao conjunto da obra, que é uma excelente apresentação da história da ciência, mesmo que seu autor negue ser um especialista no tema (:117). Chartier apresenta-se apenas como um estudioso do autor e da autoria de textos científicos na tradição da cultura europeia em diferentes contextos históricos (:119), como a corte da República das Letras ou as universidades contemporâneas, por exemplo. Nobert Elias (1897-1990), Pierre Boudieu (1930-2002) e Michael Foucault (1926-1984) são os intelectuais que marcaram a sua trajetória e o seu pensamento, segundo ele mesmo.

O objetivo de Roger Chartier em sua conferência não é tanto perguntar "o que é um autor científico?”, mas sim fazer uma crítica historiográfica ao consagrado texto de Michel Foucault (1926-1984), O que é um autor? (1960), quando argumenta que na Idade Média já existia o nome próprio dos autores nos livros do que hoje chamamos de ciência, enquanto em literatura a autoria era anônima. Este quadro se inverteu no século XVIII, ou seja, os textos literários passaram a ser assinados, enquanto os considerados científicos ficaram anônimos. 
De acordo com ele, o argumento que Chartier denomina de "quiasmo" de Foucault" não está suficientemente embasado na história.

A partir das condições culturais da invenção da ciência moderna, com uma crítica cuidadosa e fundamentada, o autor vai introduzindo exemplos que mostram a falta de argumento histórico por parte do filósofo francês, mesmo porque, como lembra Faulhaber (:25), Foucault reconhece que aquelas são dúvidas iniciais e questões apenas apontadas.

$\mathrm{Na}$ entrevista concedida a Faulhaber e Leite Lopes, Chartier contextualiza a temática, apresentando as várias correntes da história da ciência presentes na França no momento em que assumiu a direção do Centre Alexandre Koyré de Recherche em Histoire des Sciences et des Technologies (1989-1998) em Paris, além das propostas existentes no Reino Unido e nos Estados Unidos, polarizando, em última instância, aquilo que Pierre Bourdieu denomina de história imanente e história contextual.

Sempre interessado na discussão da história do autor e da autoria nos textos científicos (:37), Chartier discorre sobre a função-autor, refutando a ideia de que "[...] a construção da autoria com base nos direitos de propriedade do autor sobre sua obra não pode ser datada no final do século XVIII ou início do XIX" (:47). Apresenta vários exemplos paradigmáticos dessa construção mesmo antes da invenção da prensa mecânica de Johannes Gutemberg, cerca de 1445 (Burke, 2003), analisando os direitos de propriedade moral e econômica sobre os textos, a autoridade política e a autoria científica nos séculos XVI e XVII.

A censura, segundo ainda Chartier, contribuiu para a criação da função-autor, o copyright e a autoria, culminando com as invenções fundamentais para a escrita no século XIV, que são: os novos significados para as palavras autor, escritor e invenção; a literatura como invenção; e a conexão entre "[...] o livro como objeto, a obra e o nome de seu autor” (:60). Todos estes aspectos são relatados como invenções do "[...] desprestigiado século XIV [...]" (:60), como descontinuidades culturais e históricas que transformaram intelectualmente a cultura ocidental.

Em minha perspectiva, no entanto, o centro da problemática histórico-metodológica proposta por Chartier está em sua entrevista e no posfácio. Cabe assinalar que o mérito na apresentação da temática na entrevista deve ser creditada também às perguntas formuladas pelos organizadores que, com propriedade, apresentam questões pertinentes, e aos seus desdobramentos no mundo contemporâneo com as novas tecnologias.

$\mathrm{Na}$ entrevista, o autor responde às perguntas apresentando as diferentes posições existentes no campo acadêmico. Chartier está a todo momento preocupado 
em mostrar que a ciência também habita a história e, portanto, a sua posição como autor não é defendida como verdade universal. É um texto informativo e formativo na medida em que coloca em prática em seu discurso o que entende por ciência e qual a posição que ocupa o historiador como autor nessa controvérsia.

Chartier enriquece a discussão desde sempre presente nas humanidades -remetendo-se ao historiador italiano Carlos Ginzburg (1999) - sobre as diferenças entre as ciências humanas e as ciências hard, como a pretensão por parte de alguns autores em considerar para ambas os mesmos critérios e métodos. A dimensão quantitativa é o que caracteriza as ciências naturais desde Galileu, no século XVII, enquanto as chamadas ciências humanas seriam marcadas pela busca dos indícios, com uma verdade mais negociada historicamente. Esta problemática, enfim, é o que Chartier afirma ser a obsessão dos historiadores: a questão do estatuto da verdade na ciência. Com os conceitos de negociação, convenção e controvérsia, é possível, segundo Chartier, construir um diálogo entre a história da cultura e a história da ciência, até hoje meio que afastadas.

Penso que é esclarecedor o fato de este livro ter sido organizado por dois antropólogos: trata da escritura de textos (científicos), o que também está presente na história da antropologia desde as suas primeiras etnografias e daquilo que entre nós é conhecido como a antropologia da antropologia. Ou seja, como a historiadora Heloisa Maria Bertol Domingues comentou no livro, a partir da história da cultura e da "cultura do social" (:8), incorpora também a antropologia da ciência e do conhecimento ocidental quando, através dos conceitos de interpretação e compreensão, segundo os organizadores da obra (:12), metodologicamente escolhe falar da ciência como uma dimensão da realidade cultural, e desta como pertencente ao reino da história. Na antropologia, tal controvérsia tem sido constante, já que a disciplina tem oscilado entre ser a ciência da cultura como natureza e a ciência da cultura como história.

Uma dica para quem não está familiarizado com a temática da história da ciência, mas quer compreender como a discussão se reflete nas concepções envolvidas na escrita dos textos dos historiadores da antropologia: começar a ler os capítulos deste livro organizado por Priscila Falhauber e José Sérgio Leite Lopes de trás para frente. 


\section{Notas}

${ }^{1}$ Segundo o Dicionário Aurélio Buarque de Holanda, quiasmo é "Figura de estilo pela qual se repetem palavras invertendo-se-lhes a ordem; [... 'Tinha a alma de sonhos povoada, / E a alma de sonhos povoada eu tinha' (Olavo Bilac, Poesias, p. 126).”

\section{Referências bibliográficas}

BURKE, Peter. 2003. Uma história social do conhecimento: de Gutemberg a Diderot. Rio de Janeiro: Jorge Zahar.

Buarque de Holanda, Aurélio. 1999. Novo Aurélio. Século XXI. Rio de Janeiro: Editora Nova Fronteira.

FOUCAULT, Michael. 1994. Qu'est-cequ'um auteur? In: D. Défert \& F. Éwald. Ditsetécrits I. Paris: Gallimard.

GUINZBURG, Carlo. 1999. The judge and the historian. Marginal notes on a late-twentiethcentury miscarriage of justice. London, New York: Verso. 